\title{
Mal de Pott simulando carcinoma metastásico espinal
}

\section{Mal de Pott mimicking spinal metastatic carcinoma}

\section{Bouchentouf Rachid '}

Bouchentouf R. Mal de Pott simulando carcinoma metastásico espinal. Rev Soc Peru Med Interna. 2020;33(2):86-87.

https://doi.org//0.36393/spmi.v33i2.528

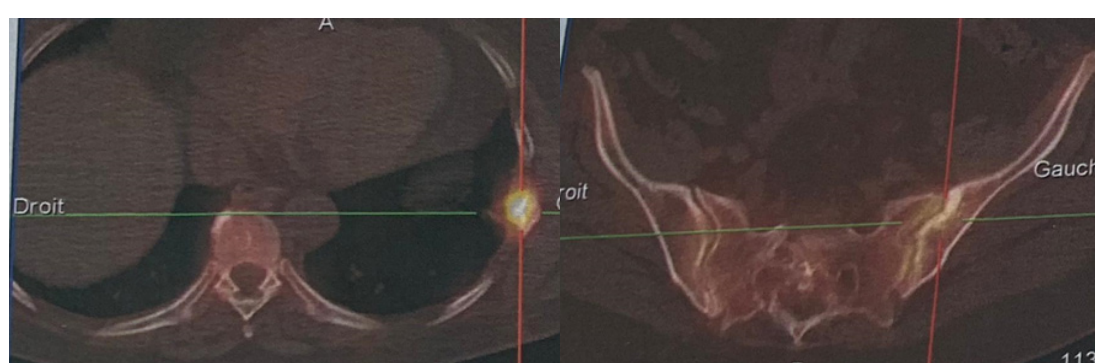

Figuras I. SPECT: fijación del radioisótopo en la séptima costilla (a) y la región sacroilíaca izquierda (b).

Mujer de 55 años de edad, con antecedentes de carcinoma papilar tiroideo tratado con $\mathrm{I}^{131}$ a dosis de $200 \mathrm{mCi}$. En el control, el SPECT mostró captación del radioisótopo en la séptima costilla y la región sacroilíaca izquierda evocando metástasis óseas (Figura $1 \mathrm{a}, 1 \mathrm{~b}$ ).

Tres meses después, apareció un dolor muy selectivo en zona lumbar inferior e izquierda en proyección de L5. La resonancia magnética evidenció disminución en la señal de la intensidad de los cuerpos vertebrales L5-S1 y disminución del espacio vertebral. Los hallazgos sugirieron lesión tuberculosa (enfermedad de Pott). Se realizó una biopsia ósea guiada por tomografía y el estudio histopatológico del tejido tomado reveló la presencia de granulomas con células epitelioides y con necrosis caseosa, confirmando el diagnóstico de tuberculosis (TB) vertebral o enfermedad de Pott. Se inició tratamiento con rifampicina, isoniacida, pirazinamida y etambutol los dos primeros meses seguido de rifampicina e isoniacida por siete meses.

La TB vertebral suele ser endémica pero la incidencia creciente del cáncer dificulta el diagnóstico de las lesiones óseas espinales. En el caso de cáncer tiroideo, las metástasis óseas son generalmente lesiones múltiples y osteolíticas en el esqueleto axial, costillas, pelvis. La RMN es el método de elección para el diagnóstico de TB vertebral por su alta sensibilidad. Pero el diagnóstico definitivo de TB o

Departamento de neumología, Hospital Militar Avicena, Marrakech. Marruecos.

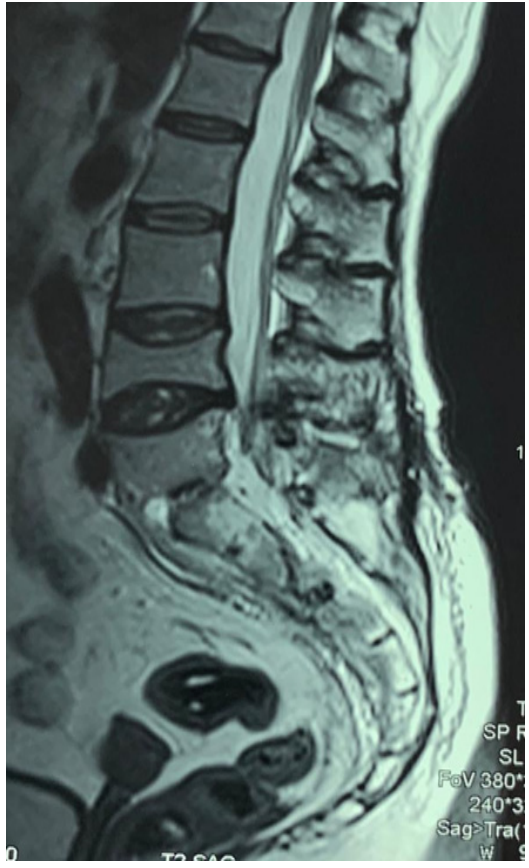

Figura 2. RMN, corte sagital: disminución del espacio vertebral L5-SI, engrosamiento de tejidos blandos de la región lumbosacra.

metástasis vertebral no sólo se basa en imágenes. La biopsia es, generalmente, necesaria para el diagnóstico final. ${ }^{1,2}$

\section{REFERENCIAS BIBLIOGRÁFICAS}

I. Chuang-Yi Z, Dong-Xin L, Shao-Wei L, Shi-Xin D. Imaging presentation highly manifested as tuberculosis in a case of spinal metastatic carcinoma. Orthopedics. 2011 ; 34(8) :436-438.

2. Momjian R, George M. Atypical imaging features of tuberculous spondylitis: case report with literature review. J Radiol Case Rep. $2014 ; 8(11): 1-14$.

\section{CORRESPONDENCIA:}

bouchentouf_rachid@yahoo.fr

Fecha de recepción: 05-05-2020. Fecha de aceptación: 25-05-2020. 
